\title{
Analisis Sistem Penyaliran Tambang pada Tailing Storage Facility (TSF) PT. Aneka Tambang Tbk. Pongkor, Kabupaten Bogor, Jawa Barat
}

\author{
Tri Winarno ${ }^{1 *}$, Rinal Khaidar Ali $^{1}$, Muh. Mursaliin ${ }^{1}$
}

${ }^{1}$ Departemen Teknik Geologi, Fakultas Teknik, Universitas Diponegoro.

\begin{abstract}
Abstrak
Pembangunan dam TSF (Tailing Storage Facility) dibangun untuk menampung limbah hasil pengolahan emas UBPE (Unit Bisnis Pertambangan Emas) PT. ANTAM Pongkor. Pembangunan dam TSF telah selesai dilaksanakan, tetapi masih menyisakan beberapa kendala tentang pengontrolan, yang pada akhirnya menimbulkan kendala teknis, yaitu tidak tersedianya lahan lagi untuk menampung tailing hingga pasca tambang. Permasalahan tersebut akan terselesaikan dengan mengetahui berapa lama penampungan TSF yang dibangun bisa menampung volume yang bertambah akibat curah hujan pada periode ulang tertentu dalam jangka waktu tiga tahun ke depan, terutama pada penampungan dam utama TSF. Untuk itu perlu diadakan evaluasi kapasitas tampung pada dam utama untuk mengetahui kemampuan pelayanan aktual TSF hingga tiga tahun ke depan. Metode yang digunakan dalam penelitian ini adalah metode penanggulangan air pada tambang terbuka atau penyaliran tambang. Perhitungan yang dilakukan adalah perhitungan curah hujan rencana, perhitungan intensitas curah hujan dan perhitungan debit air limpasan. Hasil penelitian menunjukkan bahwa tingkat pelayanan dam utama cukup untuk menampung curah hujan dengan periode ulang 2 tahunan, tetapi tidak memenuhi rencana pembangunan yang mampu menampung hingga tiga tahun ke depan. Upaya memperpanjang umur atau tingkat pelayanan adalah dengan menambahkan pompa dan pengerukan endapan tailing, selain sebagai penambahan umur bangunan juga sebagai penyeimbang. Pengerukan tailing alangkah lebih baik dilakukan pemerataan dalam pengerukannya ini berguna untuk menambah kapasitas tampung dam utama.
\end{abstract}

Kata kunci: PT. Aneka Tambang. Tbk. UBPE Pongkor; Penyaliran tambang; curah hujan; tailing.

\begin{abstract}
Construction of the TSF (Tailing Storage Facility) that is intended to accommodate the waste from UBPE PT.ANTAM Pongkor's gold processing. The construction of the TSF dam has been completed, but still leaves some constraints regarding control which ultimately creates technical obstacles, namely the unavailability of more land for the TSF as needed in planning. This raises a problem, namely how much TSF shelter is built can serve or anticipate the increasing volume that may arise due to rainfall at certain return periods in the next three years, especially at the TSF main dam shelter. For this reason, it is necessary to evaluate the capacity of the main dam to determine the actual service capacity of the current TSF on service capabilities for the next three years. The method used in this study is the mine drainage method which includes. The calculations done in this research are the calculation of rainfall plan, calculation of rainfall intensity and calculation of runoff water discharge. From the results of the study, it is known that based on the calculation of the main dam service level is sufficient to accommodate rainfall with a period of 2 years, but does not meet the development plan that can accommodate up to the next three years. So as to extend the life or level of service, the authors suggest adding pumps and dredging tailings deposits, in addition to adding the age of the building as a counterweight. Dredging of Tailings would be better done evenly in dredging it is useful to increase the capacity of the main dam.
\end{abstract}

Keywords: PT. Aneka Tambang. Tbk. UBPE Pongkor; Mine drainage method; rainfall; tailing.

\section{PENDAHULUAN}

Pertambangan adalah sebagian atau seluruh tahapan kegiatan dalam rangka penelitian, pengolahan dan pengusahaan mineral atau batubara yang meliputi penyelidikan umum, eksplorasi, studi kelayakan, kontruksi, 
penambangan, pengolahan dan pemurnian, pengangkutan dan penjualan, serta kegiatan paska tambang (UU No. 4, 2009). Salah satu kegiatan pertambangan di Pulau Jawa adalah pertambangan emas UBPE (Unit Bisnis Pertambangan Emas) PT. Aneka Tambang, Kabupaten Bogor, Jawa Barat.

Seiring dengan berjalannya waktu produksi penambangan emas pun semakin menurun dilihat dari cadangan dan potensi kandungan emas sekarang, namun di sisi lain terjadi penumpukan hasil pengolahan emas atau sering disebut limbah atau tailing. Tailing ditampung di sebuah dam atau TSF (Tailing Storage Facility) dimana pada tempat tersebut limbah B3 (limbah yang mengandung bahan berbahaya dan beracun) diolah kembali menjadi bahan berguna dan aman bagi lingkungan.

Indonesia merupakan negara yang beriklim tropis dan mempunyai curah hujan yang cukup tinggi, sehingga dalam industri pertambangan dengan tingginya curah hujan akan mempengaruhi kegiatan operasional penambangan, dengan begitu perlu dilakukan perencanaan sistem penyaliran dam TSF untuk mencegah terjadi peluapan pada penampungan tersebut.

Penyaliran tambang merupakan suatu aktivitas yang tak dapat dipisahkan dalam kegiatan operasional penambangan baik itu tambang terbuka maupun tambang bawah tanah. Beberapa parameter yang mempengaruhi dalam sistem penyaliran yaitu: tingginya curah hujan/ intensitas hujan (rainfall intensity), terpotongnya akuifer di lahan tambang sebagai akibat aktivitas penggalian yang selalu menimbulkan masalah untuk kelancaran kegiatan operasional penambangan dan rancangan dari saluran (Jusub, 2012).

Berdasarkan parameter tersebut, curah hujan di lokasi penambangan sangat tinggi sehingga debit air yang masuk pada sektor kerja tambang juga sangat tinggi, sehingga untuk penanganan seperti intensitas curah hujan, kinerja pompa dan kapasitas penampungan perlu dilakukan pengamatan sebaik mungkin, untuk meminimalisir meluapnya penampungan dan proses penambangan tidak terganggu. Dari permasalahan mengenai tinggi kenaikan air pada penampungan perlu dilakukan analisis sistem penyaliran pada penampungan demi kelancaran kegiatan penambangan dan tercapainya target produksi.

\section{METODOLOGI}

Penelitian dilakukan menggunakan metode penyaliran tambang dan analisis curah hujan Penyaliran menurut Awang (2004) adalah suatu metoda, pengontrolan atau penanggulangan air tanah dan air permukaan bumi yang biasanya mengganggu aktivitas tambang, baik tambang terbuka, bawah tanah maupun tambang batubara. Pengontrolan airtanah menjadi bagian yang tidak terpisahkan dengan aktifitas penggalian bijih atau batubara, maka faktor-faktor yang perlu dipertimbangkan antara lain sistem pengontrolan (sump, sumur dalam atau sumur pompa), curah hujan rata-rata, debit air minimum-maksimum, kualitas air dan biaya.

Penyaliran yang diuraikan ini difokuskan pada metode atau teknik penanggulangan air pada tambang terbuka. Teknik penyaliran tambang bisa bersifat pencegahan atau pengendalian air masuk ke lokasi penambangan. Salah satu metode yang digunakan dalam analisis curah hujan rencana adalah metode distribusi ekstrim atau metode distribusi Gumbel (dalam Suroso, 2006) (Persamaan 1)

$x t=\mathrm{X}+\frac{\mathrm{s}}{\mathrm{Sn}}(Y t-Y n)$

Keterangan:

$X t=$ Perkiraan nilai curah hujan rencana $(\mathrm{mm})$

$\mathrm{X}=$ Curah hujan rata-rata $(\mathrm{mm})$

$\mathrm{S}$ = Simpangan baku (standar deviasi)

$\mathrm{Sn}=$ Standar deviasi dari reduksi variate (koreksi simpangan)

Yt = Nilai reduksi variate dari variable yang diharapkan terjadi pada periode perulangan tertentu

Yn $=$ Koreksi rata rata (reduced mean)

Perhitungan intensitas curah hujan menggunakan persamaan Mononobe (dalam Suroso, 2006) (Persamaan $2 \& 3$ ).

$$
I=\frac{R 24}{24}\left(\frac{24}{t}\right)^{2 / 3}
$$

Keterangan:

I = Intensitas curah hujan $(\mathrm{mm} / \mathrm{jam})$

R24 = Curah hujan rencana per hari $(24$ jam $)$

$\mathrm{t} \quad=$ Waktu konsentrasi (jam) 
$t c=60 \times\left(0,871 \times \frac{L^{\mathrm{s}}}{H}\right)^{0,385}$

Keterangan:

$\mathrm{Tc}=$ Waktu terkumpulnya air (menit)

$\mathrm{L}=$ Jarak terjauh sampai titik pengaliran (meter)

$\mathrm{H}=$ Beda ketinggian dari titik terjauh sampai ke tempat berkumpulnya air (meter)

Perhitungan debit air limpasan dapat dihitung dengan menggunakan rumus rasional (Persamaan 4).

$$
Q=0,278 \times C \times I \times A
$$

Keterangan:

$\mathrm{Q}=$ Debit limpasan $\left(\mathrm{m}^{3} /\right.$ det $)$

$\mathrm{C}=$ Koefisien material (Koefisien limpasan)

I = Intensitas curah hujan ( $\mathrm{mm} / \mathrm{jam})$

$\mathrm{A}=$ Luas catchment area (ha)

Penelitian ini menggunakan peralatan dan bahan yang digunakan untuk kegiatan pengambilan data di lapangan dan pengolahan data. Daftar peralatan dan bahan yang dibawa dapat dilihat pada Tabel 1 .

\section{HASIL DAN PEMBAHASAN}

Dalam penelitian ini dilakukan beberapa analisis, di antaranya analisis curah hujan untuk menentukan debit limpasan air permukaan saat terjadi hujan secara maksimal. Selain analisis curah hujan, juga dilakukan beberapa analisis lainnya seperti analisis luasan penampungan serta analisis pemompaan.

\section{Analisis Curah Hujan Rencana}

Analisis curah hujan rencana dilakukan untuk memperoleh besarnya nilai curah hujan dan intensitas hujan dalam satu hari. Hujan rencana

Tabel 1. Peralatan dan Bahan

\begin{tabular}{ll}
\hline \multicolumn{1}{c}{ Alat } & \multicolumn{1}{c}{ Bahan } \\
\hline Perangkat lunak MS. Word, & \\
MS. Excel, Arc Map 10, & \\
CorelDraw X7, Global & Data curah hujan harian \\
Mapper 15, Planimeter, & \\
Autocad 2009. & \\
Sepatu Standar Lapangan & Daerah tangkapan hujan \\
Kamera Pocket & Data kinerja pompa \\
Meteran & Dimensi Penampungan \\
Kompas geologi & \\
Kalkulator & \\
Alat tulis & \\
\hline
\end{tabular}

dalam analisis ini didapatkan dari frekuensi data curah hujan yang tersedia dengan menggunakan metode partial duration seriesi atau pemilihan data curah hujan dengan nilai curah hujan tertinggi atau maksimum pada tahun 2007-2016. Berdasarkan data curah hujan, diperoleh data curah rata rata 45,39 $\mathrm{mm} / \mathrm{hari}$.

Analisis curah hujan dilakukan dengan menggunakan metode distribusi Gumbel, yang meliputi:

1. Perhitungan Standar Deviasi

$$
\begin{aligned}
& \partial=\sqrt{\frac{\sum(X i-X)^{2}}{n-1}} \\
& \partial=\sqrt{\frac{1479,049}{10-1}} \\
& \partial=12,82
\end{aligned}
$$

\section{Perhitungan Reduce Variate}

Perhitungan reduce variate menggunakan periode ulang (T) 2 tahun

$$
\begin{aligned}
& Y=-\ln \left(\ln \left(\frac{T-1}{T}\right)\right) \\
& Y=0,37
\end{aligned}
$$

3. Penentuan koreksi rata-rata (reduced mean)

$$
Y n=-\ln \left(\ln \left(\frac{n+1-m}{n+1}\right)\right)
$$

Keterangan:

$m$ =1-n urutan sample

$n \quad=10$ data curah hujan 2007-2016

$Y n=-\ln \left(\ln \left(\frac{10+1-1}{10+1}\right)\right)$

$Y n=2,35$

4. Perhitungan koreksi simpangan (reduced standart deviation)

$$
\begin{aligned}
& \partial n=\sqrt{\frac{\sum(y n-y)^{2}}{n-1}} \\
& \partial n=\sqrt{\frac{9,13}{10-1}} \\
& \partial n=1,01
\end{aligned}
$$

5. Perhitungan curah hujan rencana

Perhitungan curah hujan rencana masih menggunakan metode Gumbel dengan 
periode ulang 2 tahun, dengan perhitungan sebagai berikut:

$$
\begin{aligned}
& x t=\mathrm{X}+\frac{\partial}{\partial n}(Y t-Y n) \\
& x t=45,39+\frac{12,82}{1,01}(0,37-0,52) \\
& x t=43,48 \mathrm{~mm} / \mathrm{hr}
\end{aligned}
$$

\section{Analisis Intensitas Curah Hujan}

Intensitas curah hujan bertujuan untuk menentukan besaran hujan dalam kurun waktu tertentu (24 jam). Lamanya waktu hujan sangat mempengaruhi lebat atau tidaknya hujan tersebut, sebagai contoh hujan dalam kurun waktu 1 jam akan sangat lebat dibanding hujan dalam 24 jam, tetapi tidak menentukan banyaknya curah hujan. Analisis intensitas curah hujan menggunakan persamaan Mononobe, karena dalam persamaan ini menggunakan waktu konsentrasi $(t c)$ maka untuk menghitung waktu konsentrasi $(t c)$ menggunakan persamaan Kirpich. Berikut perhitungan dan hasil dari analisis intensitas curah hujan.

1. Perhitungan Waktu Konsentrasi (tc)

$$
\begin{gathered}
t c=60 \times\left(\frac{0,87}{1000} \times \frac{L^{2}}{s}\right)^{0,385} \\
s=\frac{H}{0,9 \times L}
\end{gathered}
$$

Keterangan:

$S=$ Kemiringan rata rata

$L=$ Panjang $/$ jarak lintasan

$H=$ Beda tinggi

$s_{\text {rata-rata }}=0,227$

$t c_{\text {rata-rata }}=6,34$ menit

2. Intensitas curah hujan

$$
I=\frac{R 24}{24}\left(\frac{24}{t}\right)^{2 / 3}
$$

Keterangan:

R24 = Curah hujan rencana ( $\mathrm{mm} / \mathrm{hari})$

$\mathrm{T}=$ Waktu konsentrasi (jam)

$$
\begin{aligned}
& I=\frac{43,48}{24}\left(\frac{24}{0,105}\right)^{2 / 3} \\
& I=67,8 \mathrm{~mm} / \mathrm{jam}
\end{aligned}
$$

\section{Debit Limpasan Rencana}

Debit rencana merupakan debit yang akan menentukan besar kecilnya dimensi bangunan penampungan air. Debit rencana menjadi bagian yang sangat penting pada saat merencanakan bangunan air atau penampungan air karena besar atau kecilnya debit akan sangat berpengaruh, sehingga dimensi bangunan air yang lebih besar dari debit rencana akan lebih aman dalam mengalirkan atau menampung debit tersebut.

1. Koefisien limpasan $(C)$

Jenis material pada areal penambangan berpengaruh terhadap kondisi penyerapan air limpasan karena untuk setiap jenis dan kondisi material yang berbeda memiliki koefisien materialnya masing-masing. Koefisien tersebut merupakan parameter yang menggambarkan hubungan curah hujan dan limpasan, yaitu memperkirakan jumlah air hujan yang mengalir menjadi limpasan langsung di permukaan (Tabel 2). Koefisien limpasan dipengaruhi oleh faktor-faktor tutupan tanah, kemiringan dan lamanya hujan.

2. Luas daerah tangkapan hujan

Luas daerah tangkapan hujan ditentukan dengan melihat morfologi daerah penelitian dengan dibatasi oleh bukit atau gunung sehingga air hujan mengalir ke daerah penampungan yang direncanakan, selain itu pada daerah tangkapan hujan tersebut terdapat alat pengukur curah hujan minimal dua alat pengukur, semakin banyak alat pengukur maka data curah hujan yg diperoleh semakin akurat. Berikut merupakan daerah tangkapan hujan pada daerah penelitian (Gambar 1).

Tabel 2. koefisien limpasan pada daerah penelitian (blok kuning), (Sayoga, 1993)

\begin{tabular}{clc}
\hline Kemiringan & \multicolumn{1}{c}{ Tutupan/jenis lahan } & $\mathrm{C}$ \\
\hline \multirow{2}{*}{ (datar) } & sawah, rawa & 0,2 \\
& Hutan, perkebunan & 0,3 \\
& Perumahan & 0,4 \\
3\% - 15\% & Hutan, perkebunan & 0,4 \\
(sedang) & Serumahan & 0,5 \\
& Lahan termak agak jarang & 0,6 \\
& Hutan & 0,7 \\
$>15 \%$ & Perumahan & 0,6 \\
(curam) & Semak-semak agak jarang & 0,7 \\
& Lahan Terbuka daerah tambang & 0,8 \\
\hline
\end{tabular}






Gambar 1. Peta situasi yang menunjukkan luasan daerah tangkapan hujan (Putra, 2013)

Pada daerah penelitian memiliki luas daerah tangkapan hujan 460.918,45 $\mathrm{m}^{2}$. Perhitungan debit rencana menggunakan persamaan Rasional dengan memiliki unsur luasan daerah tangkapan hujan, koefisien limpasan, intensitas curah hujan. Berikut perhitungan debit limpasan:

$$
\begin{aligned}
& Q=0,278 \times C \times I \times A \\
& Q=0,278 \times C \times I \times A \\
& Q=0,278 \times 0,6 \times 67,8 \times 0,46 \\
& Q=5,2 \mathrm{~m}^{3} / \text { det }
\end{aligned}
$$

\section{Debit Total}

Debit total merupakan debit air permukaan yang masuk ke dam penampungan. Debit total meliputi debit rencana ditambah dengan debit lumpur dari pabrik (feeding). Berikut perhitungan debit total:

\section{Debit total $=Q+$ feeding pabrik}

1. Feeding dari pabrik

Lumpur yang masuk ke dam penampungan merupakan limbah hasil produksi emas PT. Aneka Tambang. Lumpur ini dialirkan menggunakan pompa dan memanfaatkan elevasi, sehingga pompa yang digunakan tidak menggunakan daya yang besar. Limbah masuk ke dalam kolam lahan keruk eksisting dengan debit sebesar $1.836 \mathrm{~m}^{3} /$ hari mengandung $15 \%$ solid. Pada kolam keruk eksisting ini lumpur yang berasal dari pabrik diendapkan dengan memanfaatkan kolamkolam parit sehingga saat aliran keluar dari kolam eksisting solid yang terkandung berkurang hingga menyisakan $4,25 \%$ solid 
atau $69,7 \mathrm{~m}^{3} /$ hari menuju dam utama dengan debit sebesar 1.653,4 $\mathrm{m}^{3} /$ hari.

2. Dimensi dam penampungan utama

Dimensi dam utama memiliki luas 125.675,0094 $\mathrm{m}^{2}$ dengan ketinggian $518 \mathrm{~m}$ dari permukaan laut untuk zona aman ketinggian maksimal (PT.Antam Pongkor, 2017). Berikut acuan ketinggian maksimal untuk dimensi dam utama (Gambar 2), dan gambar Peta dam utama Cikaret (Gambar 3). Sehingga dengan begitu volume tampung dapat terhitung untuk menentukan kapasitas tersisa dari dam utama Cikaret. Berikut perhitungan volume sisa dam utama Cikaret.

Vol total $=$ luas area $\mathrm{x}$ (tinggi maks-tinggi sekarang) $=125.675,009 \times(518-515,36)$

$$
=331.782,024 \mathrm{~m}^{3}
$$

3. Debit total

Dari perhitungan volume yang tersisa dan debit yang masuk ke dalam dam utama, sangat tidak memungkinkan untuk dapat di tampung oleh dam, apabila debit rencana saat hujan berlangsung selama 24 jam.

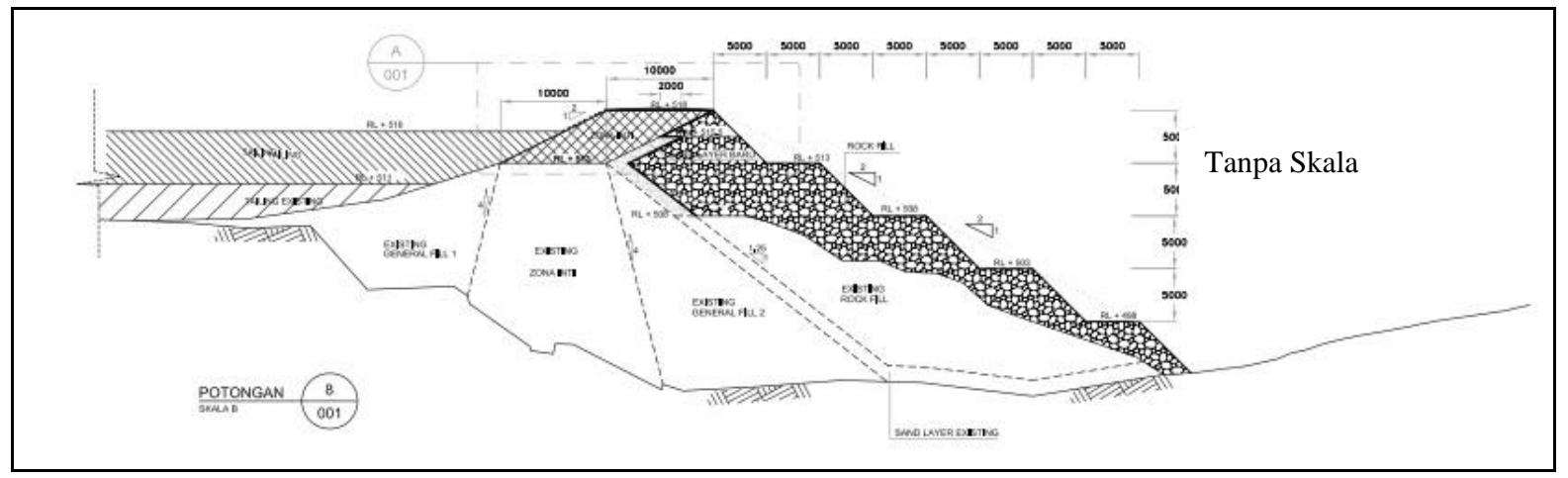

Gambar 2. As build penampang dam utama Cikaret (Putra, 2013)

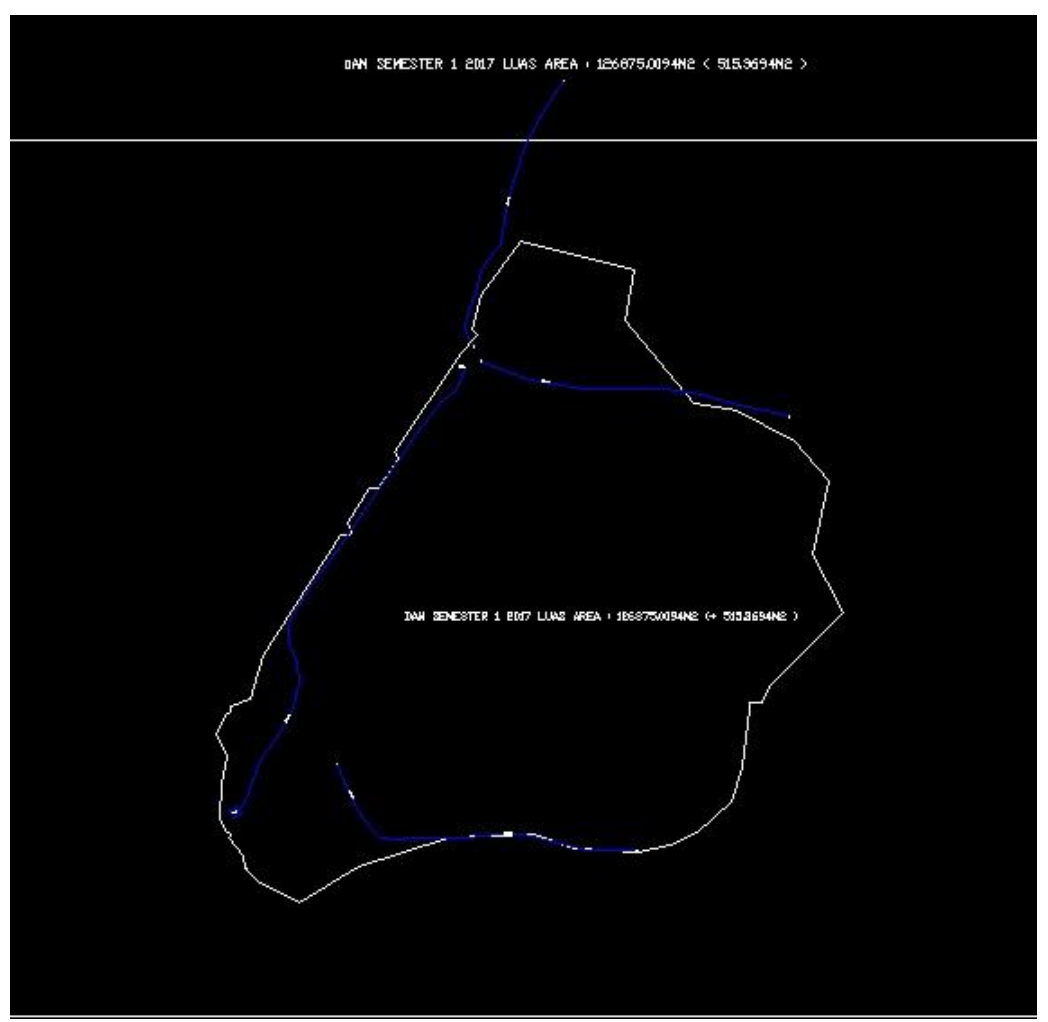

Gambar 3. Peta Dam utama Cikaret (Putra, 2013) 
Tabel 3. Perhitungan durasi pemompaan dengan debit maksimal

\begin{tabular}{lcccc}
\hline Pompa & $\begin{array}{l}\text { Durasi } \\
\text { Waktu }\end{array}$ & $\begin{array}{l}\text { Debit } \\
\text { M3/menit }\end{array}$ & $\begin{array}{l}\text { Debit } \\
\text { M3/Jam }\end{array}$ & $\begin{array}{l}\text { Debit Total x } \\
\text { Durasi } \\
\text { (m3/hari) }\end{array}$ \\
\hline DP-30 & 21 & 1,5 & 90 & 1890 \\
DP-30 & 21 & 1,5 & 90 & 1890 \\
DP-30 & 21 & 1,5 & 90 & 1890 \\
DP-50 & 21 & 3,2 & 192 & 4032 \\
DP-100 & 21 & 12 & 720 & 15120 \\
$\Sigma$ & & & 1182 & 24822 \\
\hline
\end{tabular}

Sehingga perlu dilakukkan pengeluaran debit untuk menyeimbangkan dam tersebut, diantaranya dengan menggunakan pompa dengan daya yang besar serta pengerukan timbunan lumpur untuk membesarkan volume tampungan.

$$
\begin{aligned}
\text { Debit total } & =\mathrm{Q}+\text { Feeding pabrik } \\
& =5,2 \mathrm{~m}^{3} / \text { det }+1.653 \mathrm{~m}^{3} / \text { hari } \\
& =44.928 \mathrm{~m}^{3} / \text { hari }+1.653 \mathrm{~m}^{3} / \text { hari } \\
& =46.581 \mathrm{~m}^{3} / \text { hari }
\end{aligned}
$$

\section{Analisis Kestabilan Daya Tampung}

Analisis kestabilan ini bertujuan untuk menjaga kapasitas dam penampungan agar tidak cepat meluap, diantaranya dengan pemompaan atau pengerukan timbunan tailling. Apabila nilai debit yang masuk ke dalam dam penampungan lebih besar dibanding kapasitas tampung maka akan dilakukan pengerukan timbunan lumpur dan peninggian bendungan, sedangkan apabila debit yang masuk ke dalam dam penampungan lebih kecil maka perencanaan sistem penyaliran yang diterapkan oleh perusahaan sudah sangat memadai untuk mencapai umur rencana dam sehingga tidak perlu dilakukan kestabilan lagi.

Kapasitas pompa TOYO DP-100 BL dengan head maksimum 15 meter didapatkan debit sebesar $12 \mathrm{~m}^{3} /$ menit. Durasi pemompaan maksimal yang digunakan adalah 21 jam/hari, dengan pertimbangan akan disediakan 3 jam sebagai waktu maintenance terhadap pompa.

Perhitungan debit pemompaan berdasarkan durasi pemompaan maksimum pada hari di mana debit pemasukan sangat besar atau faktor curah hujan yang tinggi dapat dilihat pada (Tabel 3).
Dari perhitungan maksimum kinerja pompa didapatkan debit pengeluaran $24822 \mathrm{~m}^{3} / \mathrm{hari}$. Dari perhitungan rencana umur bendungan dengan estimasi 3 tahun perencanaan maka dapat di hitung rencana debit yang masuk kedalam dam penampungan dalam 3 tahun ke depan, berikut rencana perhitungan dan realisasi daya tampung dam selama 3 tahun.

Volume total $=331.782,024$

Waktu $=3$ tahun $=1.080$ hari

$Q=\frac{331782,024 \mathrm{~m}^{\mathrm{a}}}{1080 \mathrm{hari}}=307 \mathrm{~m}^{3} /$ hari

Kestabilan dapat dicapai dengan mengurangi debit menjadi $307 \mathrm{~m}^{3} /$ hari dalam jangka waktu 3 tahun adalah. Tetapi dalam perhitungan debit total yang masuk kedalam dam tiap harinya didapatkan $46.581 \mathrm{~m}^{3} /$ hari sehingga perhitungan perencanaan umur tampungan dapat dihitung sebagai berikut.

$$
\begin{aligned}
\mathrm{Q} & =\left(46.581 \mathrm{~m}^{3} / \mathrm{hari}-307,2 \mathrm{~m}^{3} / \text { hari }\right)-24.822 \mathrm{~m}^{3} / \text { hari } \\
& =21.2451 \mathrm{~m}^{3} / \text { hari }
\end{aligned}
$$

Dengan begitu dari analisis yang telah dihitung didapatkan debit limpasan sebesar 5,2 $\mathrm{m}^{3} /$ detik yang kemudian dimasukkan ke dalam perhitungan perencanaan umur tampungan. Pada perencanaan umur tampungan selama 3 tahun dengan kapasitas volume sisa sebesar $331.782,024 \mathrm{~m}^{3}$ maka dam dengan kemampuan 5 pompa harus dapat mengeluarkan debit minimal sebesar 307, 20 $\mathrm{m}^{3} /$ hari nya. Tetapi dengan debit rencana hujan maksimal yang terjadi periode ulang 2 tahun dan ditambah dengan debit limbah dari pabrik setiap harinya, maka total debit yang masuk sebesar 46.273,8 $\mathrm{m}^{3} /$ hari, dengan begitu pompa akan bekerja maksimal dengan total daya yang dapat dikeluarkan 5 pompa sebesar $24.822 \mathrm{~m}^{3} /$ hari, sehingga masih terdapat debit yang belum terangkut keluar dari dam penampungan. Untuk memenuhi umur dam penampungan selama 3 tahun perlu adanya peningkatan daya pompa dengan menambah jumlah pompa untuk dapat mengeluarkan keseluruhan debit yang masuk.

\section{KESIMPULAN}

Berdasarkan hasil analisis didapatkan hasil dam penampungan dengan volume sisa $331.782,024 \mathrm{~m}^{3}$ untuk umur rencana 3 tahun, dengan debit $46.581 \mathrm{~m}^{3} /$ hari tidak akan 
memenuhi kebutuhan dalam jangka waktu 3 tahun. Untuk memenuhi umur dam penampungan selama 3 tahun perlu adanya peningkatan daya pompa dengan menambah jumlah pompa untuk dapat mengeluarkan keseluruhan debit yang masuk.

\section{UCAPAN TERIMA KASIH}

Penulis mengucapkan terima kasih kepada Unit Bisnis Pertambangan Emas PT. ANTAM Pongkor yang telah memberikan izin pemakaian data untuk penelitian ini.

\section{DAFTAR PUSTAKA}

Jusub, M.. 2012. Analisis Sitem Penyaliran Tambang pada Pit II Timur PT. Gunung Emas Abadi. Universitas Palangkaraya, Palangkaraya.

Putra, O. 2013. Proyek Akhir Kajian Teknis Tentang Persentase Pengendapan Lumpur di Backfill Pabrik PT. ANTAM Tbk UBPE Pongkor.

Sayoga, G. R., 1993. Diklat Kuliah Sistem Penyaliran Tambang. Jurusan Teknik Pertambangan ITB, Bandung.

Suroso. 2006. Analisis Curah Hujan untuk Membuat Kurva IDF di Kawasan Rawan Banjir Kabupaten Banyumas. Journal Teknik Sipil Volume 3, No.1:37-40. 